\title{
Flower-visiting insects of genus Melastoma (Myrtales: Melastomataceae) at the Fushan Botanical Garden, Taiwan
}

\author{
Joe Chun Chia Huang ${ }^{\ddagger}$, Yun Chen Hsieh§, Sheng Shan Lu§,।, Wen Chi Yeh§, Jia Yuan Liang ${ }^{\ddagger}$, \\ Chien Jung Linl, Gene Sheng Tung ${ }^{\ddagger}$ \\ ‡ Botanical Garden Division, Taiwan Forestry Research Institute, Taipei, Taiwan \\ $\S$ Forest Protection Division, Taiwan Forestry Research Institute, Taipei, Taiwan \\ | Fushan Research Center, Taiwan Forestry Research Institute, Yuan Shan Township, Taiwan
}

Corresponding author: Gene Sheng Tung (gene.tung@gmail.com)

Academic editor: Yasen Mutafchiev

Received: 03 Nov 2020 | Accepted: 17 Dec 2020 | Published: 26 Jan 2021

Citation: Huang JCC, Hsieh YC, Lu SS, Yeh WC, Liang JY, Lin CJ, Tung GS (2021) Flower-visiting insects of genus Melastoma (Myrtales: Melastomataceae) at the Fushan Botanical Garden, Taiwan. Biodiversity Data Journal 9: e60315. https://doi.org/10.3897/BDJ.9.e60315

\begin{abstract}
Background

We investigated the diversity and behaviour of insects that visit flowers of four native Melastoma (Family Melastomataceae) species of Taiwan and a horticultural hybrid Melastoma species at the Fushan Botanical Garden, Taiwan biweekly from May to August 2020. Visits of flower-visiting insects were classified into seven behavioural categories, based on the insects' behaviour and positions on the flower. The data are further assigned into four insect-flower interactions, namely pollination, herbivory, commensalism and neutralism. Our goal is to provide baseline data of insect-plant interactions of Melastoma, which is a common, but understudied plant genus in the country.
\end{abstract}




\section{New information}

A total of 1,289 visits to flowers were recorded by at least 63 insect morphospecies belonging to seven orders. The number of insect species recorded per Melastoma species ranged from 9 to 39. Visiting, sonication and passing were the three most frequently recorded types of behaviour, collectively accounting for $90.2 \%$ ( $n=1,240)$ of the total observations. Pollination was the most dominant insect-flower interaction, accounting for $70.2 \%$ of the total observations, followed by neutralism $(20.0 \%)$, herbivory $(6.3 \%)$ and commensalism (3.5\%). Sweat bees of the genera Lasioglossum and Maculonomia (Hymenoptera: Halictidae) are considered key pollinators to Melastoma species in Fushan Botanical Garden, based on their high number of visits and sonication behaviour. Our study provides the first list of insects that visit the flowers of all Taiwan's known Melastoma species and description of their interactions with the plants.

\section{Keywords}

buzz pollination, Lasioglossum, Maculonomia, Melastoma kudoi, sonication

\section{Introduction}

With over 5,000 species, Melastomataceae represents one of the largest Angiosperm families distributed in the subtropical and tropical regions around the world (POWO 2019). Members of this flowering family have a complicated evolutionary history (Renner 1993, Stein and Tobe 1989) and exhibit diverse morphological traits (Dellinger et al. 2018, Renner 1989, Varassin et al. 2008) and reproduction biology (Dellinger et al. 2019, dos Santos et al. 2012, Peng et al. 2014). The diversification of Melastomataceae is partially a result of hybridisation events. Interspecific hybridisation within a genus (Dai et al. 2012, Hawkins et al. 2016) and between genera (Hawkins et al. 2016, Zhou et al. 2020) have been reported. Empirical studies suggest that hybridisation in some genera of Melastomataceae are likely mediated by specialised insect pollinators. The pollination syndrome in Melastomataceae is mainly, but not exclusively, dependent on bees (superfamily Apoidea) that are able to vibrate pollen from poricidal anthers by sonication (Renner 1989). Although interspecific hybridisation via insect pollinators has been observed in Melastomataceae native to Asia, studies on insect-flower interactions in Melastomataceae are largely focused on New World species (e.g. Brito et al. 2016, Brito et al. 2017, Pereira et al. 2011, Renner 1989).

There are 18 species belonging to 12 genera of Melastomataceae in Taiwan (Huang and Huang 1996). Of these, Melastoma is the most speciose genus with four species. Two of which, namely Melastoma kudoi Sasaki and M. scaberrima (Hayata) (previously known as Otanthera scaberrima, but see Yang and Liu 2002) are endemic to the Island country, whereas the other two species, M. candidum D. Don and M. malabathricum L. are widely distributed in Asia, the Pacific and Australia (GBIF Secretariat 2019). Amongst the four species, $M$. kudoi is the rarest species, which has only been recorded from the type locality 
in central Taiwan. The population of $M$. kudoi is considered highly threatened and included in the national Red List (Editorial Committee of the Red List of Taiwan Plants 2017, listed as $M$. intermedia Dunn, but see the recent taxonomy revision by Dai et al. 2019) due to habitat disturbance and lack of inclusion in protected areas (Huang and Huang 1996). The other three Melastoma species can be commonly found in the lowlands up to mid-altitude mountainous areas (Huang and Huang 1996). Despite the great richness of Melastoma species in Taiwan, information about pollinators of these species is limited.

To date, only one study on the pollination biology of one Melastoma species, $M$. candidum, in Taiwan has been published (Liu et al. 2008). Noteworthy, interspecific hybridisation in this genus is often observed in both wild and cultivated plants in China and Southeast Asia (Cai et al. 2019, Wu et al. 2019, Zhou et al. 2017). Although genetic introgression has not been reported from Taiwan, co-occurrence of congeners, including the endangered and endemic M. kudoi, is common in Taiwan (C.J. Lin, unpublished data). Moreover, studies show that the primary pollinators for Melastoma species are non-specialised bees (e.g. Amegilla, Nomia (Maculonomia) and Xylocopa bees for M. affine (M. malabathricum), Gross 1993; Bombus, Nomia (Maculonomia) and Xylocopa bees for M. candidum, Liu et al. 2008). These generalist bees are also widely distributed in Taiwan (WCY and SSL, unpublished data) and their habitats commonly overlap with Melastoma species in the country. Whether these bees would visit all Melastoma species remains unknown. Therefore, understanding the pollinator fauna of all Melastoma species in Taiwan is essential to protect the Melastoma diversity, particularly the two endemic species, from potential genetic introgression. In the present project, we present the first checklist of flower-visiting insects of all known Melastoma species in Taiwan, based on empirical data.

\section{Project description}

Funding: Project of Future Plants

\section{Sampling methods}

Study extent: Established in 1990, Fushan Botanical Garden (FBG) (2445'21.2"N, $121^{\circ} 35^{\prime} 43.5^{\prime \prime E}$ ) is located in the mountainous area in the northeast of Taiwan Island (Fig. 1). The garden is part of the Fushan Experimental Forest, which covers approximately 1,098 ha. The vegetation is characterised mainly by natural broad-leaf forest, dominated by trees of the families Lauraceae and Fagaceae (Su et al. 2010). The region has a subtropical monsoon climate and is generally humid throughout the year. The mean temperature of $18.4^{\circ} \mathrm{C}$ ranging from $10^{\circ} \mathrm{C}$ to $30^{\circ} \mathrm{C}$ and peaks in the summer season (JuneAugust). The annual rainfall is $3,787 \mathrm{~mm}$, with more rain during the typhoon season (late August-October) (Lu and Huang 2013). The study was conducted at the garden's nursery and surrounding trails. 


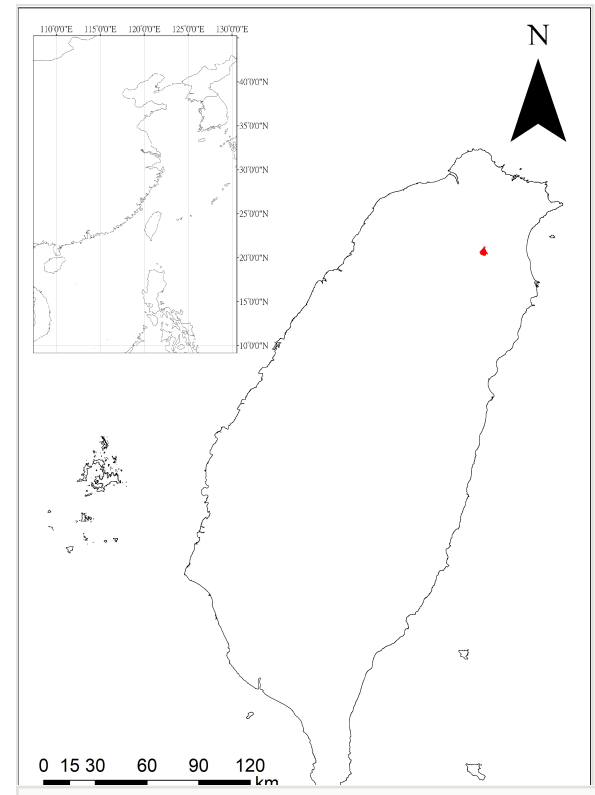

Figure 1. doi

Fushan Botanical Garden, Taiwan. The red polygon delineates the Fushan Experimental Forest.

\section{Sampling description: Melastoma flower visiting insect survey}

Data on the diversity of insects that visited the flowers of all Melastoma species were obtained biweekly at FBG from 7 May 2020 to 19 August 2020. Melastoma species included M. malabathricum L., M. candidum D. Don, M. kudoi Sasaki and M. scaberrima (Hayata). We primarily follow the taxonomy of Yang and Liu (2002), but treat $M$. septemnervium as a synonym of $M$. candidum as suggested by the backbone of most catalogues (GBIF Secretariat 2019). Melastoma malabathricum is the only species of the four that is native to this region of Taiwan (CJL, unpublished data). For M. candidum, we included both the typical purple-flowered form and the white-flowered form. Ten wild $M$. malabathricum individuals were selected along the trails adjacent to the nursery. For the remaining species, including the white flower variant of $M$. candidum, 10-15 planted individuals for each type/species were used from the nursery. Ten planted individuals of a horticultural hybrid of $M$. scaberrima and $M$. kudoi (tentatively named as Melastoma kudoi $x$ Melastoma scaberrima) were also included. For each survey session, observations of insects were made by 2-4 people at the same time for two consecutive days. The observation began roughly 45 mins after sunrise, usually between 6:30 am and 6:45 am and ended at around 11:30 am when flowers began closing or were out of pollen $(\mathrm{JCCH}$, unpublished data). In the early stage of the study by mid-June 2020 , continuous observations were made for M. malabathricum in the trails and the rest of the species in the nursery alternatively at 20-min intervals. After the end of $M$. malabathricum flowering season in mid-June, the observations were made continuously for all samples in the nursery site. Additional data, made by random observations outside of the scheduled 
survey sessions during the weekly phenology suvey (usually one hour in the morning) in another project during the same period, were also included to maximise our understanding of the diversity of flower-visiting insects. Taxa and behaviour (see the next section for details) of insects with body length $>3 \mathrm{~mm}$ present on the adaxial surface of flowers were recorded. Insects were identified visually in the field to the finest taxonomy level, whenever possible. For pollinators that could not be identified in the field, 1-3 individuals of each morphospecies were collected using a butterfly net or a plastic bag. All insect species were identified morphologically, following existing keys (Dubitzky et al. 2008, Hsu et al. 2018, Johnson and Triplehorn 2005, Starr 1992).

\section{Behaviour and insect-flower interaction classification}

Types of behaviour of insects visiting flowers of Melastoma species were recorded by direct observations in the field. Further confirmations were made, based on pictures and videos taken using phone cameras. Seven behaviour categories were defined, depending on how insects interact with the flower and the location on the flower where the behaviour occurred, namely sonication, visiting, stamen herbivory, petal herbivory, recycling, drinking and passing (Table 1, Fig. 2). We did not include pollen theft, another important insect behaviour related to interactions with flowers reported in other studies (e.g. Hargreaves et al. 2009). Despite bees often being observed placing their mouth parts at the porous dehiscence of the anther during our observation, there was no evidence that they removed pollen grains from the anthers. In many cases, bees stepped on anthers before they inserted their tongues and then sonicate the anthers afterwards. In other cases, especially near the end of the flowering season or at the last two hours before flowers closed, bees often left the flowers without sonicating the anthers after they performed such behaviour. Therefore, instead of pollen theft, we assume that bees assess pollen capacity of the anthers using both mouth parts and legs before they decide to buzz flowers. Under this context, both types of behaviour were included into the category of visiting. The observations of insect behaviour were further assigned into four types of insect-plant interactions, namely pollination, herbivory, commensalism and neutralism, based upon expected direct effects of each behaviour category for both insects and flowers (Table 1).

Table 1.

The interactions, definitions and expected effects of the seven types of behaviour of insects that were observed to visit the flowers of Melastoma species. "+", "-" and "0" signs denote positive, negative and neutral effects, respectively, of each type of behaviour on the insect (before the left slash) and the plant (after the left slash).

\begin{tabular}{|l|l|l|l|}
\hline $\begin{array}{l}\text { Insect-flower } \\
\text { interaction }\end{array}$ & $\begin{array}{l}\text { Type of } \\
\text { behaviour }\end{array}$ & $\begin{array}{l}\text { Sign of } \\
\text { expected } \\
\text { effect }\end{array}$ & Definition \\
\hline Pollination & Sonication & $+/+$ & $\begin{array}{l}\text { Emit buzz sounds when contacting stamens or pistil, producing } \\
\text { vibrations that attempt to expel pollen out from anthers }\end{array}$ \\
\hline
\end{tabular}




\begin{tabular}{|c|c|c|c|}
\hline $\begin{array}{l}\text { Insect-flower } \\
\text { interaction }\end{array}$ & $\begin{array}{l}\text { Type of } \\
\text { behaviour }\end{array}$ & $\begin{array}{l}\text { Sign of } \\
\text { expected } \\
\text { effect }\end{array}$ & Definition \\
\hline & Visiting & $0 / 0,0 /+$ & $\begin{array}{l}\text { Contact any part of pistil and stamens without consuming and } \\
\text { collecting materials and cause no obvious damage to the } \\
\text { reproductive organs }\end{array}$ \\
\hline \multicolumn{4}{|l|}{ Herbivory } \\
\hline & $\begin{array}{l}\text { Stamen } \\
\text { herbivory }\end{array}$ & $+/-$ & Damage stamens, but not the anthers \\
\hline & $\begin{array}{l}\text { Petal } \\
\text { herbivory }\end{array}$ & $+/-$ & Damage petals \\
\hline \multicolumn{4}{|l|}{ Commensalism } \\
\hline & Recycling & $+/ 0$ & $\begin{array}{l}\text { Consume pollens expelled by other insects from the flower and } \\
\text { water, usually on the petals, but occasionally at the female and } \\
\text { male organs }\end{array}$ \\
\hline & Drinking & $+/ 0$ & Consume secretion from the flower \\
\hline \multicolumn{4}{|l|}{ Neutralism } \\
\hline & Passing & $0 / 0$ & $\begin{array}{l}\text { Contact only the petals without consuming and collecting } \\
\text { materials and cause no obvious damage to the petals }\end{array}$ \\
\hline
\end{tabular}
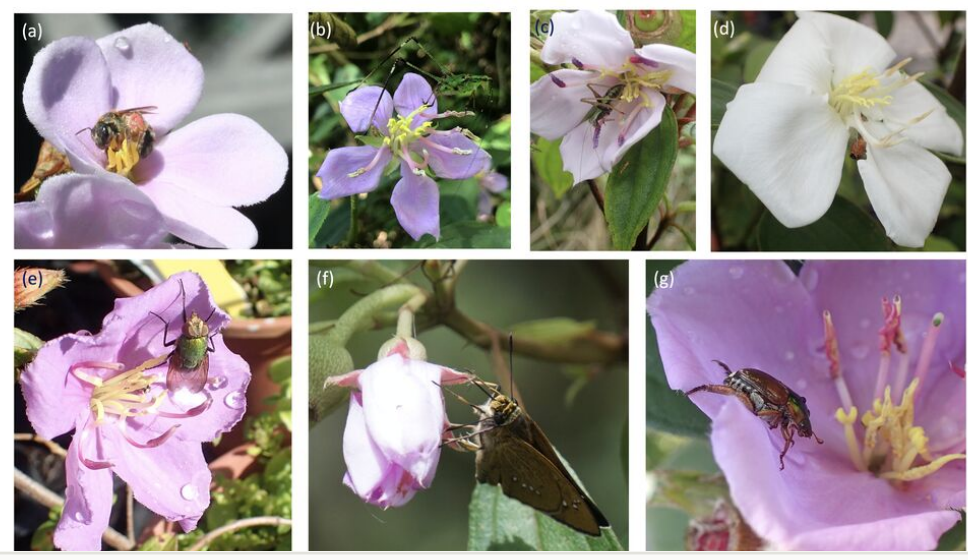

Figure 2. doi

Examples of the seven types of flower-visiting behaviour exhibited by insects on Melastoma species: sonication (a), visiting (b), stamen herbivory (c), petal herbivory (d), recycling (e), drinking (f) and passing (g).

\section{Geographic coverage}

Description: Fushan Botanical Garden, north-eastern Taiwan

Coordinates: 24.755 and 24.755 Latitude; 121.595 and 121.595 Longitude. 


\section{Taxonomic coverage}

Description: 63 insect morphospecies belonging to seven orders that are associated with five Melastoma plant species, including a horticultural hybrid.

Taxa included:

\begin{tabular}{|l|l|l|}
\hline Rank & Scientific Name & Common Name \\
\hline class & Insecta & insect \\
\hline order & Coleoptera & beetle \\
\hline order & Hymenoptera & bee, wasp, hornet \\
\hline order & Diptera & fly, midge \\
\hline order & Hemiptera & bug, plant hopper \\
\hline order & Lepidoptera & moth, butterfly, caterpillar \\
\hline order & Blattodea & cockroach \\
\hline order & Orthoptera & grasshopper, cricket \\
\hline
\end{tabular}

\section{Temporal coverage}

Notes: $2020-05-07$ through 2020-08-19

\section{Collection data}

Collection name: Forest Arthropod Collection of Taiwan

Specimen preservation method: pinned

\section{Usage licence}

Usage licence: Creative Commons Public Domain Waiver (CC-Zero)

IP rights notes: This work is licensed under a Creative Commons Attribution Non Commercial (CC-BY-NC) 4.0 License.

\section{Data resources}

Data package title: Flower visiting insects of Melastoma in Taiwan

Resource link: https://www.gbif.org/dataset/51b39c28-ce6f-4c7f-ba01-261748411e31 
Alternative identifiers: https://ipt.taibif.tw/resource?r=taiwanmelastomapollinator; 51b39c28-ce6f-4c7f-ba01-261748411e31

\section{Number of data sets: 1}

Data set name: Flower-visiting insects of Melastoma in Taiwan

\section{Data format: Darwin Core}

Description: This resource (Huang et al. 2020) is a summary of the flower-visiting insect occurrence records, based on the observations of this project. The information of flower visiting and flower are addressed in "occurrenceRemarks" and "associatedTaxa", respectively. The dataset is in Darwin Core and published on GBIF.

\begin{tabular}{|c|c|}
\hline Column label & Column description \\
\hline occurrencelD & $\begin{array}{l}\text { An identifier for the Occurrence (as opposed to a particular digital record of the } \\
\text { occurrence). In the absence of a persistent global unique identifier, construct one } \\
\text { from a combination of identifiers in the record that will most closely make the } \\
\text { occurrencelD globally unique. }\end{array}$ \\
\hline basisOfRecord & The specific nature of the data record. \\
\hline eventDate & $\begin{array}{l}\text { The date-time or interval during which an Event occurred. For occurrences, this is } \\
\text { the date-time when the event was recorded. Not suitable for a time in a geological } \\
\text { context. }\end{array}$ \\
\hline country & The name of the country or major administrative unit in which the Location occurs \\
\hline county & $\begin{array}{l}\text { The full, unabbreviated name of the next smaller administrative region than } \\
\text { stateProvince (county, shire, department etc.) in which the Location occurs. }\end{array}$ \\
\hline municipality & $\begin{array}{l}\text { The full, unabbreviated name of the next smaller administrative region than county } \\
\text { (city, municipality etc.) in which the Location occurs. Do not use this term for a } \\
\text { nearby named place that does not contain the actual location. }\end{array}$ \\
\hline locality & $\begin{array}{l}\text { The specific description of the place. Less specific geographic information can be } \\
\text { provided in other geographic terms (higherGeography, continent, country, } \\
\text { stateProvince, county, municipality, waterBody, island, islandGroup). This term may } \\
\text { contain information modified from the original to correct perceived errors or } \\
\text { standardise the description. Comments }\end{array}$ \\
\hline minimumElevationInMetres & $\begin{array}{l}\text { The lower limit of the range of elevation (altitude, usually above sea level), in } \\
\text { metres. }\end{array}$ \\
\hline decimalLatitude & $\begin{array}{l}\text { The geographic latitude (in decimal degrees, using the spatial reference system } \\
\text { given in geodeticDatum) of the geographic centre of a Location. Positive values } \\
\text { are north of the Equator, negative values are south of it. Legal values lie between } \\
-90 \text { and } 90 \text {, inclusive. }\end{array}$ \\
\hline
\end{tabular}




\begin{tabular}{|c|c|}
\hline decimalLongitude & $\begin{array}{l}\text { The geographic longitude (in decimal degrees, using the spatial reference system } \\
\text { given in geodeticDatum) of the geographic centre of a Location. Positive values } \\
\text { are east of the Greenwich Meridian, negative values are west of it. Legal values lie } \\
\text { between }-180 \text { and } 180 \text {, inclusive. }\end{array}$ \\
\hline geodeticDatum & $\begin{array}{l}\text { The ellipsoid, geodetic datum or spatial reference system (SRS) upon which the } \\
\text { geographic coordinates given in decimalLatitude and decimalLongitude are based. }\end{array}$ \\
\hline coordinateUncertaintylnMetres & $\begin{array}{l}\text { The horizontal distance (in metres) from the given decimalLatitude and } \\
\text { decimalLongitude describing the smallest circle containing the whole of the } \\
\text { Location. Leave the value empty if the uncertainty is unknown, cannot be } \\
\text { estimated or is not applicable (because there are no coordinates). Zero is not a } \\
\text { valid value for this term. }\end{array}$ \\
\hline scientificName & $\begin{array}{l}\text { The full scientific name, with authorship and date information if known. When } \\
\text { forming part of an Identification, this should be the name in the lowest level } \\
\text { taxonomic rank that can be determined. This term should not contain identification } \\
\text { qualifications, which should instead be supplied in the IdentificationQualifier term. }\end{array}$ \\
\hline kingdom & The full scientific name of the kingdom in which the taxon is classified. \\
\hline phylum & The full scientific name of the phylum or division in which the taxon is classified. \\
\hline class & The full scientific name of the class in which the taxon is classified. \\
\hline order & The full scientific name of the order in which the taxon is classified. \\
\hline family & The full scientific name of the family in which the taxon is classified. \\
\hline genus & The full scientific name of the genus in which the taxon is classified. \\
\hline specificEpithet & The name of the first or species epithet of the scientificName. \\
\hline infraspecificEpithet & $\begin{array}{l}\text { The name of the lowest or terminal infraspecific epithet of the scientificName, } \\
\text { excluding any rank designation. }\end{array}$ \\
\hline taxonRank & The taxonomic rank of the most specific name in the scientificName. \\
\hline identificationRemarks & Comments or notes about the Identification. \\
\hline lifeStage & $\begin{array}{l}\text { The age class or life stage of the biological individual(s) at the time the Occurrence } \\
\text { was recorded. }\end{array}$ \\
\hline vernacularName & A common or vernacular name. \\
\hline associatedTaxa & $\begin{array}{l}\text { A list (concatenated and separated) of identifiers or names of taxa and their } \\
\text { associations with the Occurrence. }\end{array}$ \\
\hline behaviour & $\begin{array}{l}\text { A description of the behaviour shown by the subject at the time the Occurrence } \\
\text { was recorded. }\end{array}$ \\
\hline fieldNumber & $\begin{array}{l}\text { An identifier given to the event in the field. Often serves as a link between field } \\
\text { notes and the Event. }\end{array}$ \\
\hline catalogNumber & An identifier (preferably unique) for the record within the dataset or collection. \\
\hline
\end{tabular}




\begin{tabular}{|l|l|}
\hline institutionCode & $\begin{array}{l}\text { The name (or acronym) in use by the institution having custody of the object(s) or } \\
\text { information referred to in the record. }\end{array}$ \\
\hline recordedBy & $\begin{array}{l}\text { A list (concatenated and separated) of names of people, groups or organisations } \\
\text { responsible for recording the original Occurrence. The primary collector or } \\
\text { observer, especially one who applies a personal identifier (recordNumber), should } \\
\text { be listed first. }\end{array}$ \\
\hline
\end{tabular}

\section{Additional information}

\section{Results}

A total of 1,298 insect visits were observed, which generated 911 occurrence records of flower-visiting insects, of which more than one-third of the visits were made to the horticultural hybrid species, Melastoma kudoi x Melastoma scaberrima $(n=437)$. Of the remaining observations, $12-19 \%$ were recorded for each of the remaining species/forms and only $3.8 \%$ of the observations were recorded for $M$. scaberrima. Around $15.6 \%$ and $56.3 \%$ of the insects sampled could be identified to species and genus, respectively and the rest are identified to family or higher levels (Table 2). The number of insect taxa recorded from each Melastoma species ranged from 9 to 39 morphospecies, for a total across all Melastoma species of at least 63 insect morphospecies of seven orders (Table 2).

\section{Table 2.}

Diversity of flower-visiting insects and the accumulative number of visits for each Melastoma species.

\begin{tabular}{|c|c|c|c|c|c|c|}
\hline & $\begin{array}{l}\text { M. } \\
\text { malabathricum }\end{array}$ & $\begin{array}{l}\text { M. candidum } \\
\text { purple- } \\
\text { flowered form }\end{array}$ & $\begin{array}{l}\text { M. candidum } \\
\text { white- } \\
\text { flowered form }\end{array}$ & $\begin{array}{l}\text { M. } \\
\text { kudoi }\end{array}$ & $\begin{array}{l}\text { M. } \\
\text { scaberrima }\end{array}$ & Hybrid \\
\hline \multicolumn{7}{|l|}{ Blattodea } \\
\hline \multicolumn{7}{|l|}{ Blaberoidea } \\
\hline \multicolumn{7}{|l|}{ Ectobiidae } \\
\hline Symploce sp. & 1 & & & & & \\
\hline \multicolumn{7}{|l|}{ Coleoptera } \\
\hline \multicolumn{7}{|l|}{ Chrysomeloidea } \\
\hline \multicolumn{7}{|l|}{ Chrysomelidae } \\
\hline Arthrotus tricolor & 1 & & & & & \\
\hline Basilepta varians & 3 & & & & & \\
\hline Lagria sp. & 1 & & & & & \\
\hline Monolepta hieroglyphica & & & & & & 1 \\
\hline
\end{tabular}




\begin{tabular}{|c|c|c|c|c|c|c|}
\hline & $\begin{array}{l}\text { M. } \\
\text { malabathricum }\end{array}$ & $\begin{array}{l}\text { M. candidum } \\
\text { purple- } \\
\text { flowered form }\end{array}$ & $\begin{array}{l}\text { M. candidum } \\
\text { white- } \\
\text { flowered form }\end{array}$ & $\begin{array}{l}\text { M. } \\
\text { kudoi }\end{array}$ & $\begin{array}{l}\text { M. } \\
\text { scaberrima }\end{array}$ & Hybrid \\
\hline Monolepta signata & & & 5 & 5 & 1 & 26 \\
\hline Nonarthra chengi & & & & & & 1 \\
\hline Nonarthra sp. & & 1 & & & & \\
\hline Theopea sauteri & 2 & & & 1 & & 6 \\
\hline Unidentified leaf beetle & 7 & & 4 & 1 & & 4 \\
\hline \multicolumn{7}{|l|}{ Elateroidea } \\
\hline \multicolumn{7}{|l|}{ Elateridae } \\
\hline Elateridae gen. sp. & 2 & & & & & \\
\hline \multicolumn{7}{|l|}{ Scarabaeoidea } \\
\hline \multicolumn{7}{|l|}{ Scarabaeidae } \\
\hline Cetoniinae gen. sp. & & & 3 & & & \\
\hline Popillia livida & & & 4 & & & \\
\hline Popillia taiwana & & 1 & 2 & & & \\
\hline Scarabaeidae gen. sp. & 1 & & 2 & & & \\
\hline \multicolumn{7}{|l|}{ Tenebrionoidea } \\
\hline \multicolumn{7}{|l|}{ Mordellidae } \\
\hline Mordellidae gen. sp. & & & 1 & & & \\
\hline Unidentified coleopteran & 1 & & 1 & & & \\
\hline \multicolumn{7}{|l|}{ Diptera } \\
\hline \multicolumn{7}{|l|}{ Ephydroidea } \\
\hline \multicolumn{7}{|l|}{ Drosophilidae } \\
\hline Drosophilidae gen sp. & 3 & & & & & \\
\hline \multicolumn{7}{|l|}{ Muscoidea } \\
\hline \multicolumn{7}{|l|}{ Anthomyiidae } \\
\hline Anthomyia illocata & & & 1 & & & \\
\hline \multicolumn{7}{|l|}{ Oestroidea } \\
\hline \multicolumn{7}{|l|}{ Calliphoridae } \\
\hline Calliphoridae gen. sp. & & & 3 & 1 & & 13 \\
\hline Chrysomya sp.1 & 5 & 4 & 2 & & & 2 \\
\hline Chrysomya sp.2 & & 3 & 2 & 1 & & 3 \\
\hline \multicolumn{7}{|l|}{ Sciaroidea } \\
\hline Sciaridae & & & & & & \\
\hline
\end{tabular}




\begin{tabular}{|c|c|c|c|c|c|c|}
\hline & $\begin{array}{l}\text { M. } \\
\text { malabathricum }\end{array}$ & $\begin{array}{l}\text { M. candidum } \\
\text { purple- } \\
\text { flowered form }\end{array}$ & $\begin{array}{l}\text { M. candidum } \\
\text { white- } \\
\text { flowered form }\end{array}$ & $\begin{array}{l}\text { M. } \\
\text { kudoi }\end{array}$ & $\begin{array}{l}\text { M. } \\
\text { scaberrima }\end{array}$ & Hybrid \\
\hline Sciaridae gen. sp. & 2 & & & & & \\
\hline \multicolumn{7}{|l|}{ Syrphoidea } \\
\hline \multicolumn{7}{|l|}{ Syrphidae } \\
\hline Episyrphus balteatus & 1 & & & & & \\
\hline Paragus sp. & 1 & & & & & \\
\hline Sphaerophoria sp. & 1 & & & & & \\
\hline Syrphidae gen. sp. & 9 & & 2 & & 1 & 1 \\
\hline \multicolumn{7}{|l|}{ Tephritoidea } \\
\hline \multicolumn{7}{|l|}{ Tephritidae } \\
\hline Spathulina acroleuca & & 1 & & & & 1 \\
\hline Unidentified dipteran & 8 & & 4 & 2 & 2 & 8 \\
\hline \multicolumn{7}{|l|}{ Hemiptera } \\
\hline \multicolumn{7}{|l|}{ Coreoidea } \\
\hline \multicolumn{7}{|l|}{ Coreidae } \\
\hline Coreidae sp. & 1 & & & & & \\
\hline \multicolumn{7}{|l|}{ Fulgoroidea } \\
\hline Unidentified planthopper & 1 & & & & & \\
\hline \multicolumn{7}{|l|}{ Lygaeoidea } \\
\hline \multicolumn{7}{|l|}{ Geocoridae } \\
\hline Geocoris varius & 1 & & & & & \\
\hline \multicolumn{7}{|l|}{ Miroidea } \\
\hline \multicolumn{7}{|l|}{ Miridae } \\
\hline Eurystylus sp. & & & 1 & & & 1 \\
\hline Pilophorus formosanus & & 2 & 6 & & & \\
\hline Miridae gen. sp. & 2 & & 1 & & & \\
\hline \multicolumn{7}{|l|}{ Reduvoidea } \\
\hline Reduviidae & 1 & & & & & \\
\hline Reduviidae gen. sp. & 1 & & & & & \\
\hline Unidentified bug & 5 & & 3 & & & 1 \\
\hline \multicolumn{7}{|l|}{ Hymenoptera } \\
\hline \multicolumn{7}{|l|}{ Apoidea } \\
\hline Apidae & & & & & & \\
\hline
\end{tabular}




\begin{tabular}{|c|c|c|c|c|c|c|}
\hline & $\begin{array}{l}\text { M. } \\
\text { malabathricum }\end{array}$ & $\begin{array}{l}\text { M. candidum } \\
\text { purple- } \\
\text { flowered form }\end{array}$ & $\begin{array}{l}\text { M. candidum } \\
\text { white- } \\
\text { flowered form }\end{array}$ & $\begin{array}{l}\text { M. } \\
\text { kudoi }\end{array}$ & $\begin{array}{l}\text { M. } \\
\text { scaberrima }\end{array}$ & Hybrid \\
\hline Amegilla calceifera & 1 & & & & & \\
\hline Amegilla sp. & 5 & 1 & 2 & 1 & & \\
\hline Amegilla urens & 2 & & & & & 1 \\
\hline Apis cerana & & & 6 & & & 4 \\
\hline Bombus eximius/flavescens & 3 & 1 & 2 & & & 4 \\
\hline Bombus flavescens & 1 & & & & & \\
\hline Ceratina pulchripes & 4 & & 2 & & & \\
\hline Ceratina sauteri & & & & & 2 & \\
\hline Ceratina sp. & 4 & & 1 & 1 & 1 & \\
\hline Xylocopa dejeanii sauteri & & 1 & & & & 2 \\
\hline Xylocopa rufipes & 12 & & & & & \\
\hline Xylocopa tranquebarorum & & 8 & 7 & 1 & & 4 \\
\hline \multicolumn{7}{|l|}{ Halictidae } \\
\hline Lasioglossum formosae & 8 & 2 & 5 & 1 & & 2 \\
\hline $\begin{array}{l}\text { Lasioglossum } \\
\text { scaphonotum }\end{array}$ & 2 & & & & & \\
\hline $\begin{array}{l}\text { Lasioglossum subopacum } \\
\text { subopacum }\end{array}$ & 1 & 1 & 1 & 1 & 2 & \\
\hline Lasioglossum sp. & 15 & 33 & 92 & 31 & 5 & 105 \\
\hline Maculonomia planiventris & 1 & & & & & \\
\hline Maculonomia proxima & & 2 & & 1 & & 2 \\
\hline Maculonomia sp. & 1 & 50 & 31 & 63 & 15 & 162 \\
\hline \multicolumn{7}{|l|}{ Megachilidae } \\
\hline Megachile rufovittata & 1 & & & & & \\
\hline Megachile sp. & 2 & & & & & \\
\hline \multicolumn{7}{|l|}{ Vespidae } \\
\hline Vespa velutina & & & & 2 & & 2 \\
\hline Vespidae gen. sp. & & & 1 & & & \\
\hline Unidentified bee & 11 & & 1 & & 4 & \\
\hline \multicolumn{7}{|l|}{ Formicoidea } \\
\hline \multicolumn{7}{|l|}{ Formicidae } \\
\hline Crematogaster sp. & 17 & 4 & & 1 & & \\
\hline
\end{tabular}




\begin{tabular}{|c|c|c|c|c|c|c|}
\hline & $\begin{array}{l}\text { M. } \\
\text { malabathricum }\end{array}$ & $\begin{array}{l}\text { M. candidum } \\
\text { purple- } \\
\text { flowered form }\end{array}$ & $\begin{array}{l}\text { M. candidum } \\
\text { white- } \\
\text { flowered form }\end{array}$ & $\begin{array}{l}\text { M. } \\
\text { kudoi }\end{array}$ & $\begin{array}{l}\text { M. } \\
\text { scaberrima }\end{array}$ & Hybrid \\
\hline Formicidae gen. sp. & 22 & 32 & 23 & 27 & 12 & 51 \\
\hline Myrmicinae sp. & & 1 & 1 & & & \\
\hline Polyrhachis sp. & 1 & 1 & & 4 & 1 & 7 \\
\hline Tetraponera thagatensis & 1 & & & & & \\
\hline \multicolumn{7}{|l|}{ Ichneumonoidea } \\
\hline $\begin{array}{l}\text { Unidentified parasitoid } \\
\text { wasp }\end{array}$ & & 1 & 7 & 7 & & 17 \\
\hline \multicolumn{7}{|l|}{ Braconidae } \\
\hline Braconidae gen. sp. & 1 & & 3 & 1 & & 1 \\
\hline \multicolumn{7}{|l|}{ Ichneumonidae } \\
\hline Ichneumonidae sp. & & & 1 & & & \\
\hline Unidentified hymenopteran & & & 1 & & & \\
\hline \multicolumn{7}{|l|}{ Lepidoptera } \\
\hline \multicolumn{7}{|l|}{ Arctiidae } \\
\hline Arctiidae gen. sp. & 1 & & & & & \\
\hline \multicolumn{7}{|l|}{ Erebidae } \\
\hline Euproctis sp. & 2 & 2 & 7 & 1 & & \\
\hline \multicolumn{7}{|l|}{ Noctuidae } \\
\hline Noctuidae gen. sp. & 1 & & & & & \\
\hline \multicolumn{7}{|l|}{ Papilionoidea } \\
\hline \multicolumn{7}{|l|}{ Hesperiidae } \\
\hline Borbo cinnara & & & 1 & & & \\
\hline Hesperiidae gen. sp. & 1 & 2 & 3 & 1 & & 3 \\
\hline \multicolumn{7}{|l|}{ Lycaenidae } \\
\hline Lycaenidae gen. sp. & & & & & 1 & \\
\hline \multicolumn{7}{|l|}{ Nymphalidae } \\
\hline Athyma selenophora & & & & & & 1 \\
\hline \multicolumn{7}{|l|}{ Papilionidae } \\
\hline Graphium sarpedon & & & & & & 1 \\
\hline Unidentified butterfly & 9 & 1 & 1 & 3 & 2 & \\
\hline \multicolumn{7}{|l|}{ Orthoptera } \\
\hline Unidentified orthopteran & 1 & & 1 & & & \\
\hline
\end{tabular}




\begin{tabular}{|c|c|c|c|c|c|c|}
\hline & $\begin{array}{l}\text { M. } \\
\text { malabathricum }\end{array}$ & $\begin{array}{l}\text { M. candidum } \\
\text { purple- } \\
\text { flowered form }\end{array}$ & $\begin{array}{l}\text { M. candidum } \\
\text { white- } \\
\text { flowered form }\end{array}$ & $\begin{array}{l}\text { M. } \\
\text { kudoi }\end{array}$ & $\begin{array}{l}\text { M. } \\
\text { scaberrima }\end{array}$ & Hybrid \\
\hline \multicolumn{7}{|l|}{ Acridoidea } \\
\hline Unidentified grasshopper & 2 & 5 & & & & \\
\hline \multicolumn{7}{|l|}{ Acrididae } \\
\hline $\begin{array}{l}\text { Xenocatantops } \\
\text { brachycerus }\end{array}$ & 3 & & & & & \\
\hline \multicolumn{7}{|l|}{ Tettigonioidea } \\
\hline Unidentified bush cricket & 5 & & & & & \\
\hline \multicolumn{7}{|l|}{ Tettigoniidae } \\
\hline Conocephalus melas & 3 & & & & & \\
\hline Mecopoda sp. & 2 & & & & & \\
\hline Mecopodinae gen. sp. & 3 & & & & & \\
\hline
\end{tabular}

Visiting, sonication and passing were the three most commonly-recorded types of behaviour, comprising $37.3 \%, 32.8 \%$ and $20.0 \%$, respectively, of the total observations of behaviour $(n=1,240)$. The other four behaviour categories only accounted for less than $10.0 \%$ of the total observations. With 870 observations, pollination was the most dominant insect-flower interaction recorded on Melastoma species, followed by neutralism $(n=248)$, herbivory $(n=78)$ and commensalism $(n=44)$.

Pollinating insects that demonstrated sonication behaviour were exclusively bees in families Apidae and Halictidae (Hymenoptera: Superfamily Apoidea). Amongst all sonicating bees, sweat bees of genera Lasioglossum and Maculonomia were the two most common taxa, accounting for $89 \%$ of all flower visits (Fig. 3). There was a higher diversity of pollinator taxa showing visiting behaviour than other types of behaviour on Melastoma flowers, including insects of 22 families of all seven orders. Lasioglossum and Maculonomia bees, adult insects of Coleoptera (mainly families Chrysomelidae and Elateroidea) and Formicidae (Hymenoptera) were the four most frequently encountered taxa in our samples (Table 1Fig. 4).

\section{Discussion}

This study provides the first checklist of flower-visiting insects to all Melastoma species in Taiwan with an emphasis on insect-plant interactions, based on our field observations. Our data show a diverse flower-visiting insect fauna of at least 63 morphospecies which is higher than observations in similar studies on Melastoma (Gross 1993, Liu et al. 2008, Peng et al. 2014, Peng et al. 2012). The majority of the insects exhibited sonicating and visiting behaviour, which presumably can be linked to pollination interaction. Buzzpollinating bees of the families Apidae and Halictidae and particularly members of the genera Lasioglossum and Maculonomia, were the most common pollinators of Melastoma 
plants in our study site. These findings support the previous conclusion that this genus is primarily buzz-pollinated and highly dependent on bees for pollination.

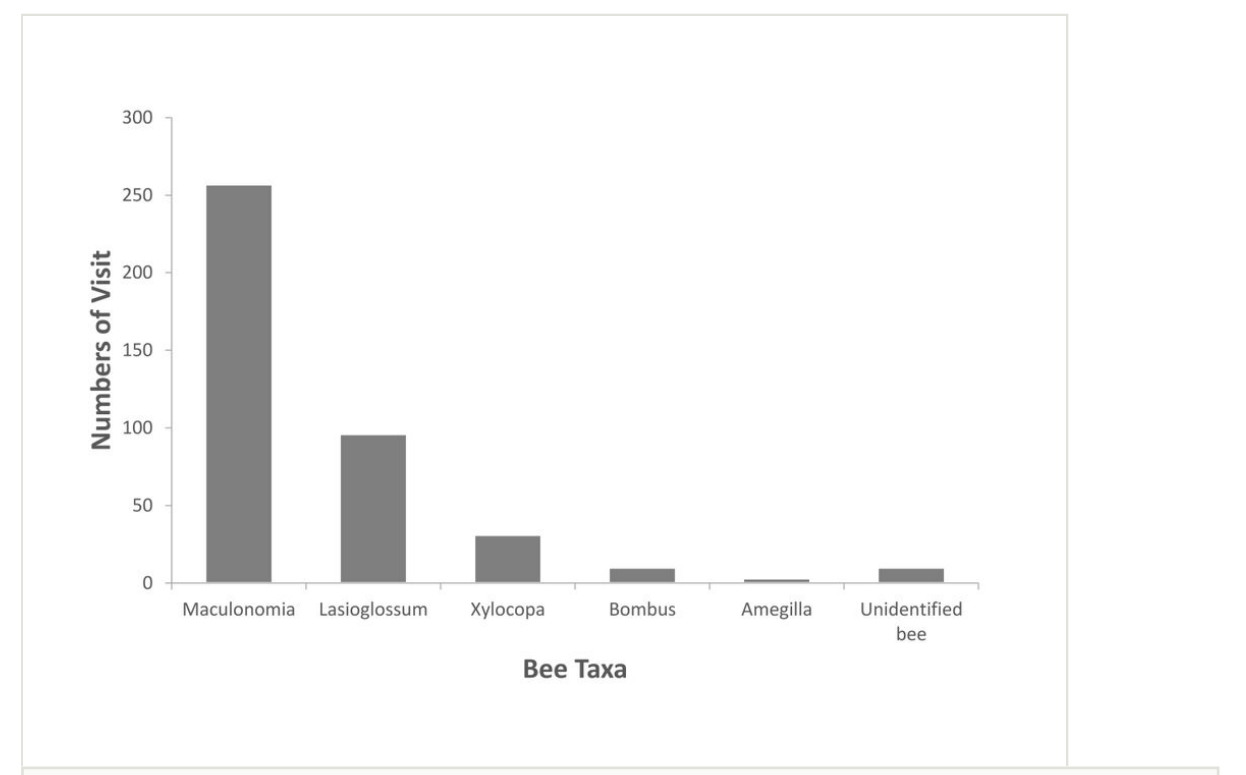

Figure 3. doi

Number of visit by different bee taxa that exhibit sonicating behaviour on flowers of Melastoma species.

Despite the commonality in the dependence of buzz-pollinating bees, our results reveal a different bee pollinator composition to other studies on Melastoma plants, even for the same plant species. Liu et al. (2008) studied pollination biology of Melastoma candidum and other three confamiliar species in Melastomataceae in central Taiwan and found that bees of genera Bambus and Xylocopa (both Apidae) are the primary pollinators. Studies on M. malabathricum (affine) in Australia (Gross 1993) reported Xylocopa, Amegilla (family Apidae) and Nomia (Maculonomia) as the main pollinators. Studies on several Melastoma species in southern China suggested that Bambus and Xylocopa, as well as Amegilla bees, are the most important pollinators (Liu et al. 2008, Luo et al. 2008, Peng et al. 2012, Peng et al. 2014). Except Maculonomia bees, these common bee pollinators of Melastoma , particularly the genus Amegilla, represent the minority in our observations.

The discrepancy between studies could be explained by the variations in local bee fauna. Landscape features (Ferreira et al. 2013, Sritongchuay and Bumrungsri 2016), elevation effect (Hoiss et al. 2015) and biogeography (Traveset et al. 2016) could greatly shape bee assemblages and associated pollination networks via trait-filtering resource partitioning and phenological mismatches between pollinators and plants. This might not be the case in this study, because Amegilla and Bambus bees are both considered common and abundant at the Fushan Botanical Garden (WCY and SSL, unpublished data). For example, Amegilla were abundant at the nursery, but rarely visited Melastoma flowers throughout the study period ( $\mathrm{JCCH}, \mathrm{YCH}, \mathrm{WCY}$ and SSL, unpublished data). A possible cause of the shifted 
pollination niches is that local bees might not recognise the experimental Melastoma plants as an available food resource (Williams 2002) since three of the four plant species are not native to Fushan. Nevertheless, lack of experience cannot completely explain why these bees did not visit the native M. malabathricum often. Other studies show that inter-specific competition of pollinators and pollens mediated by floral neighbourhoods (Bruckman and Campbell 2014) and the presence of a super pollinator (Gross and Mackay 1998, Thomson 2004), respectively, could also significantly change the pollinator-plant partnership. Further studies are necessary to clarify the causes of the shifted pollination network in Fushan.

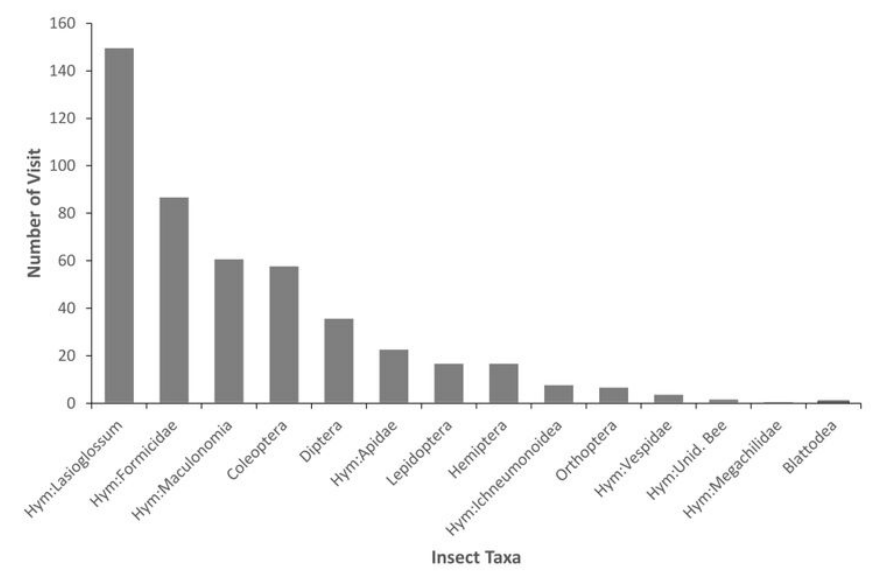

Figure 4. doi

Number of visits by different insect taxa that exhibit pollinating behaviour on flowers of Melastoma species. On the x-axis, Hym denotes order Hymenoptera; Unid. Bee denotes unidentified bee.

The occurrence of herbivores and their damage to flower structures could supress the pollination process in several ways. First, complete loss of stamens and pollens inside certainly terminate the further chances of pollen transferring. Konzmann et al. (2020) demonstrated that physical modification of anthers could greatly affect the efficiency of pollen-spreading to bees in a neotropical Melastomataceae species. In this case, bees may fail to load pollen to their body if they sonicate damaged stamens, regardless of the amount of pollen remaining inside. Loss and modification of stamen(s) and petal(s) could also reduce the chance of flowers being visited by bees as these floral traits are often found as a resource guide in Melastomataceae plants (Larson and Barrett 1999, Luo et al. 2008). Moreover, in our observations, many herbivorous insects, particularly those with large body size, hindered other flower visitors by active-guarding behaviour or simply covering the reproductive organs with their body (as shown in Fig. 2c). Such trait-mediated processes, mediated by flower herbivores, could also diminish the pollination process at an early stage (Gonçalves-Souza et al. 2008). 
While reproduction biology is recognised as an essential part of plant conservation, identifying key pollinators and pollination mechanisms becomes fundamental (Havens et al. 2006, Moza and Bhatnagar 2007). Without such information, cultivation of closelyrelated species with high hybridisation potential, as observed in Melastoma (Dai et al. 2012, Liu et al. 2014, Wu et al. 2019) in ex situ collection sites, may increase chances of genetic introgression (Lozada-Gobilard et al. 2020). The hybridisation risk in ex situ collections might be more severe for sanctuaries in the tropics as most countries in the tropical regions usually have mega-diverse flora, but often grow high numbers of species in a confined area due to lack of sufficient infrastructure. Noteworthy, Target 8 of the Global Strategy for Plant Conservation aims to preserve at least $75 \%$ of threatened species of global flora by 2020 . Following the Target, many national and regional botanical gardens, for example, Taiwan Forestry Research Institute, have been expanding their ex situ collections since 2012 (Botanic Gardens Conservation International 2012). Further studies on how environmental and ecological factors may drive pollination networks are helpful in preventing ex situ plant conservation from accidental hybridisation events.

\section{Acknowledgements}

This study is supported financially by the Project of Future Plants to GST. We thank Yider Hsu and nursery staff of Fushan Research Center for various level of support to the field work and experimental setting-up, Ming-Jer Yeh for assisting mapping, Le Tuan Quan for sharing insect pictures, Melissa Jean-Yi Liu of TAIBIF for technical support of data publication to GBIF and Tian-Chuan Hsu for suggestions of Melastoma taxonomy. We also appreciate the valuable comments from the editors and reviewers to both the dataset and manuscript.

\section{Author contributions}

JCCH and GST designed the experiment. GST acquired funding. JCCH, CJL and GST setup and maintained the experimental plants in the nursery. $\mathrm{JCCH}, \mathrm{YCH}$ and SSL contributed to fieldwork. $\mathrm{JCCH}, \mathrm{YCH}, \mathrm{WCY}$ and $\mathrm{SSL}$ identified insect samples. $\mathrm{YCH}$ prepared the specimens. $\mathrm{JCCH}, \mathrm{YCH}$ and $\mathrm{JYL}$ cleaned and formatted the data. $\mathrm{JCCH}$ wrote the first draft. YCH, SSL, YCH, JYL, CJL and GST are the joint co-authors with equal contribution.

\section{References}

- Botanic Gardens Conservation International (2012) GSPC: Global Strategy for Plant Conservation: a Guide to the GSPC: All the Targets, Objectives and Facts.

URL: https://www.bgci.org/files/Plants2020/popular_guide/englishguide.pdf

- $\quad$ Brito VLG, Fendrich TG, Smidt EC, Varassin IG, Goldenberg R (2016) Shifts from specialised to generalised pollination systems in Miconieae (Melastomataceae) and their relation with anther morphology and seed number. Plant Biology 18 (4): 585-93. https://doi.org/10.1111/plb.12432 
- $\quad$ Brito VLG, Maia FR, Silveira FAO, Fracasso CM, Lemos-Filho JP, Fernandes GW, Goldenberg R, Morellato LPC, Sazima M, Staggemeier VG (2017) Reproductive phenology of Melastomataceae species with contrasting reproductive systems: contemporary and historical drivers. Plant Biology 19 (5): 806-817. https://doi.org/ 10.1111/plb.12591

- $\quad$ Bruckman D, Campbell D (2014) Floral neighborhood influences pollinator assemblages and effective pollination in a native plant. Oecologia 176 (2): 465-476. https://doi.org/ 10.1007/s00442-014-3023-6

- $\quad$ Cai Y, Wang F, Tan G, Hu Z, Wang Y, Ng WL, Wu W, Liu Y, Zhou R (2019) Hybridization of Bornean Melastoma: implications for conservation of endemic plants in Southeast Asia. Botany Letters 166 (2): 117-124. https://doi.org/10.1080/23818107.2019.1585284

- Dai J, Lin C, Zhou Q, Li C, Zhou R, Liu Y (2019) The specific status of Melastoma kudoi (Melastomataceae, Melastomeae). Botanical Studies 60 (1). https://doi.org/10.1186/ s40529-019-0253-2

- $\quad$ Dai S, Wu W, Zhang R, Liu T, Chen Y, Shi S, Zhou R (2012) Molecular evidence for hybrid origin of Melastoma intermedium. Biochemical Systematics and Ecology 41: 136-141. https://doi.org/10.1016/j.bse.2011.12.010

- Dellinger A, Scheer L, Artuso S, Fernández-Fernández D, Sornoza F, Penneys D, Tenhaken R, Dötterl S, Schönenberger J (2019) Bimodal pollination systems in Andean Melastomataceae involving birds, bats, and rodents. The American Naturalist 194 (1): 104-116. https://doi.org/10.1086/703517

- Dellinger AS, Chartier M, Fernández-Fernández D, Penneys DS, Alvear M, Almeda F, Michelangeli FA, Staedler Y, Armbruster WS, Schönenberger J (2018) Beyond buzzpollination - departures from an adaptive plateau lead to new pollination syndromes. The New Phytologist 221 (2): 1136-1149. https://doi.org/10.1111/nph.15468

- dos Santos APM, Fracasso CM, Luciene dos Santos M, Romero R, Sazima M, Oliveira PE (2012) Reproductive biology and species geographical distribution in the Melastomataceae: a survey based on New World taxa. Annals of Botany 110 (3): 667-79. https://doi.org/10.1093/aob/mcs125

- Dubitzky A, Yang JT, Schönitzer K (2008) Historical and recent investigations on the bee fauna of Taiwan (Hymenoptera, Apoidea). Mitteilungen der Deutschen Gesellschaft für Allgemeine und Angewandte Entomologie 16: 105-108.

- Editorial Committee of the Red List of Taiwan Plants (2017) The Red List of Vascular Plants of Taiwan, 2017. [2017 臺灣維管束植物紅皮書名錄]. Endemic Species Research Institute, Forestry Bureau, Council of Agriculture, Executive Yuan and Taiwan Society of Plant Systematics, 187 pp. [In Chinese, English]. [ISBN 978-986-05-5021-4]

- Ferreira P, Boscolo D, Viana B (2013) What do we know about the effects of landscape changes on plant-pollinator interaction networks? Ecological Indicators 31: 35-40. https://doi.org/10.1016/j.ecolind.2012.07.025Ferreira,P.A.,Boscolo,D.andViana,B.F

- $\quad$ GBIF Secretariat (2019) Melastoma L. in GBIF Backbone Taxonomy. Global Biodiversity Information Facility. URL: https://doi.org/10.15468/39omei

- Gonçalves-Souza T, Omena P, Souza J, Romero G (2008) Trait-mediated effects on flowers: artificial spiders deceive pollinators and decrease plant fitness. Ecology 89 (9): 2407-13. https://doi.org/10.1890/07-1881.1

- $\quad$ Gross C, Mackay D (1998) Honeybees reduce fitness in the pioneer shrub Melastoma affine (Melastomataceae). Biological Conservation 86 (2): 169-178. https://doi.org/ 10.1016/S0006-3207(98)00010-X 
- $\quad$ Gross CL (1993) The breeding system and pollinators of Melastoma affine (Melastomataceae); A pioneer shrub in Tropical Australia. Biotropica 25 (4): 468-474. https://doi.org/10.2307/2388870

- Hargreaves A, Harder L, Johnson S (2009) Consumptive emasculation: the ecological and evolutionary consequences of pollen theft. Biological Reviews 84 (2): 259-276. https://doi.org/10.1111/j.1469-185x.2008.00074.x

- Havens K, Vitt P, Maunder M, Guerrant E, Dixon K (2006) Ex situ plant conservation and beyond. BioScience 56 (6): 525-531. https://doi.org/ 10.1641/0006-3568(2006)56[525:ESPCAB]2.0.CO;2

- Hawkins S, Ruter J, Robacker C (2016) Interspecific and intergeneric hybridization in Dissotis and Tibouchina. HortScience 51 (4): 325-329. https://doi.org/10.21273/hortsci. $\underline{51.4 .325}$

- Hoiss B, Krauss J, Steffan-Dewenter I (2015) Interactive effects of elevation, species richness and extreme climatic events on plant-pollinator networks. Global Change Biology 21 (11): 4086-97. https://doi.org/10.1111/gcb.12968

- Hsu YF, Liang JY, Huang CW (2018) Butterfly fauna of Taiwan. Vol. II. Pieridae. [臺灣蝶 類誌 第二卷 粉蝶科]. 2. Forestry Bureau, Taipei, 224 pp. [ISBN 978-986-05-5156-3]

- Huang JCC, Hsieh YC, Lu SS, Yeh WC, Liang JY, Lin CJ, Tung GS (2020) Flower visiting insects of Melastoma in Taiwan. Version 1.8. Taiwan Forestry Research Institute. Accessed via GBIF.org on 2020-10-12. https://doi.org/10.15468/64ufkd

- Huang SF, Huang TC (1996) Melastomataceae. In: Bouforrd DV, Hsieh CF, Huang TC, Ohashi H, Yang YP, Lu SY (Eds) Flora of Taiwan. 2, 2. National Taiwan University, Taipei. URL: https://tai2.ntu.edu.tw/ebook.php?ebook=Fl.\%20Taiwan\%202nd [ISBN 957-9019-92-4].

- Johnson NF, Triplehorn CA (2005) Borror and DeLong's introduction to the study of insects. CA: Thompson Brooks/Cole, Belmont, 865 pp. [ISBN 0030968356]

- Konzmann S, Hilgendorf F, Niester C, Rech AR, Lunau K (2020) Morphological specialization of heterantherous Rhynchanthera grandiflora (Melastomataceae) accommodates pollinator diversity. Plant Biology 22 (4): 583-590. https://doi.org/ 10.1111/plb.13102

- $\quad$ Larson B, Barrett S (1999) The pollination ecology of buzz-pollinated Rhexia virginica (Melastomataceae). American Journal of Botany 86 (4): 502-511. https://doi.org/ 10.2307/2656811

- $\quad$ Liu SC, Wen HH, Chen MY, Yang JT (2008) Study on pollination ecology of four species of Melastomataceae in Taiwan. Formosan Entomologist 28: 67-85. [In Chinese].

- $\quad$ Liu T, Chen Y, Chao L, Wang S, Wu W, Dai S, Wang F, Fan Q, Zhou R (2014) Extensive hybridization and introgression between Melastoma candidum and M. sanguineum. PLOS One 9 (5): p.e96680.. https://doi.org/10.1371/journal.pone.0096680

- Lozada-Gobilard S, Pánková H, Zhu J, Stojanova B, Münzbergová Z (2020) Potential risk of interspecific hybridization in ex situ collections. Journal for Nature Conservation 58 https://doi.org/10.1016/i.jnc.2020.125912

- Luo Z, Zhang D, Renner S (2008) Why two kinds of stamens in buzz-pollinated flowers? Experimental support for Darwin's division-of-labour hypothesis. Functional Ecology 22 (5): 794-800. https://doi.org/10.1111/j.1365-2435.2008.01444.x

- $\quad$ Lu SY, Huang HH (2013) Analysis of climatic attributes and dynamics of Fushan Experimental Forest. Forestry Research Newsletter 20 (6): 69-73. [In Chinese]. 
- Moza M, Bhatnagar A (2007) Plant reproductive biology studies crucial for conservation. CURRENT SCIENCE-BANGALORE- 92 (9): 1207.

- $\quad$ Peng D, Lan S, Wu S (2012) Studies on pollination biology of Melastoma sanguineum Sims (Melastomataceae). Journal of Tropical and Subtropical Botany 20 (6): 618-625. [In In Chinese with English abstract].

- $\quad$ Peng D, Lan S, Wu S (2014) Pollination biology and breeding system of Melastoma dendrisetosum. Forest Research, Beijing 27 (1): 11-16. [In Chinese with English abstract].

- $\quad$ Pereira AC, da Silva JB, Goldenberg R, Melo GA, Varassin IG (2011) Flower color change accelerated by bee pollination in Tibouchina (Melastomataceae). FloraMorphology, Distribution, Functional Ecology of Plants 206 (5): 491-497. https://doi.org/ 10.1016/i.flora.2011.01.004

- POWO (2019) Plants of the World Online. Facilitated by the Royal Botanic Gardens, Kew. Published on the Internet. http://www. plantsoftheworldonline.org/. Accessed on: 2020-9-08.

- Renner O (1993) Phylogeny and classification of the Melastomataceae and Memecylaceae. Nordic Journal of Botany 13: 519-540. https://doi.org/10.1111/j. 1756-1051.1993.tb00096.x

- Renner S (1989) A survey of reproductive biology in Neotropical Melastomataceae and Memecylaceae. Annals of the Missouri Botanical Garden 76 (2): 496-518.

https://doi.org/10.2307/2399497

- $\quad$ Sritongchuay T, Bumrungsri S (2016) Effects of forest proximity on fruit set and visitor body size of Sandoricum koetjape (Burm. f.) Merr. in Southern Thailand. Malayan Nature Journal 69 (1): 91-98.

- $\quad$ Starr CK (1992) The bumble bees (Hymenoptera: Apidae) of Taiwan. Bulletin of National Museum of Natural Science 3: 139-157.

- Stein B, Tobe H (1989) Floral nectaries in Melastomataceae and their systematic and evolutionary implications. Annals of the Missouri Botanical Garden 76 (2).

https://doi.org/10.2307/2399498

- $\quad$ Su SH, Hsieh CF, Chang-Yang CH, Lu CL, Guan BT (2010) Micro-topographic differentiation of the tree species composition in a subtropical submontane rainforest in northeastern Taiwan. Taiwan Journal of Forestry Science 25: 63-80.

- Thomson D (2004) Competitive interactions between the invasive European honey bee and native bumble bees. Ecology 85 (2): 458-470. https://doi.org/10.1890/02-0626

- Traveset A, Tur C, Trøjelsgaard K, Heleno R, Castro-Urgal R, Olesen J (2016) Global patterns of mainland and insular pollination networks. Global Ecology and Biogeography 25 (7): 880-890. https://doi.org/10.1111/geb.12362

- Varassin IG, Penneys D, Michelangeli F (2008) Comparative anatomy and morphology of nectar-producing Melastomataceae. Annals of Botany 102 (6): 899-909.

https://doi.org/10.1093/aob/mcn180

- Williams N (2002) Use of novel pollen species by specialist and generalist solitary bees (Hymenoptera: Megachilidae). Oecologia 134 (2): 228-37. https://doi.org/10.1007/ s00442-002-1104-4

- Wu R, Zou P, Tan G, Hu Z, Wang Y, Ning Z, Wu W, Liu Y, He S, Zhou R (2019) Molecular identification of natural hybridization between Melastoma malabathricum and Melastoama beccarianumin Sarawak, Malaysia. Ecology and Evolution 9 (10): 5766-5776. https://doi.org/10.1002/ece3.5160 
- Yang YP, Liu HY (2002) Nomenclature changes for some dicots of Taiwan. Taiwania 47 (2): 175-178.

- Zhou Q, Cai Y, Ng WL, Wu W, Dai S, Wang F, Zhou R (2017) Molecular evidence for natural hybridization between two Melastoma species endemic to Hainan and their widespread congeners. Biodiversity Science 25 (6): 638-646. https://doi.org/10.17520/ biods.2017060

- $\quad$ Zhou S, Ni S, Dai J, Zhou Q, Zhou R, Liu Y (2020) Natural hybridization between Phyllagathis and Sporoxeia species produces a hybrid without reproductive organs. PLOS One 15 (1). https://doi.org/10.1371/journal.pone.0227625 